\title{
Financial Development in Vietnam: An Overview
}

\author{
Toan Ngoc BUI ${ }^{1}$
}

Received: July 03, 2020 Revised: July 28, 2020 Accepted: August 10, 2020

\begin{abstract}
In this paper, we provide an overview of financial development in Vietnam. Particularly, a new approach of this study is to measure financial development through improvements in depth, efficiency and access of the banking system and stock market. Further, the study examines the factors significantly affecting financial development in Vietnam. The data are collected in Vietnam, an emerging country with a limited financial development. We employ the Autoregressive Distributed Lag (ARDL) approach, which generates a high reliability and suits data characteristics of emerging countries like Vietnam. We observe that Vietnam's banking system plays a key role in supplying credits to the economy while the nascent stock market at a limited size shows its potential for a considerable growth in the future. We also find the influential determinants of financial development in Vietnam including real estate market (RE), economic growth (EG), consumer price index (CPI), and global financial crisis (GFC). These findings are essential for Vietnamese authorities in providing practical solutions in order to build a sustainable and synchronous financial development. They are also first empirical evidence relating to an overview of financial development in an emerging country, so they are not only valuable to Vietnam but also crucial to other emerging economies.
\end{abstract}

Keywords: Financial Access, Financial Depth, Financial Development, Financial Efficiency, Vietnam

JEL Classification Code: E44, G20, G21

\section{Introduction}

Financial development is an interesting topic which is a big concern of many empirical studies. The analysis of financial development provides researchers a comprehensive perspective on capacity of financial institutions in supplying financial services to other economic entities (Schumpeter, 1911). Financial development also enables an effective allocation of resources (Cherif \& Dreger, 2016). That is why financial development is crucial in boosting the economic growth (Bencivenga \& Smith, 1998; Bong \& Premaratne, 2020; Bui, 2019a; Camba \& Camba, 2020; Greenwood \& Jovanovic, 1990; Tran \& Nguyen, 2020), and more notably, cutting poverty (Kousar, Rais, Mansoor, Zaman, Shah, \&

${ }^{1}$ First Author and Corresponding Author. Faculty of Finance and Banking, Industrial University of Ho Chi Minh City (IUH), Vietnam [Postal Address: No. 12, Nguyen Van Bao Street, Ward 4, Go Vap District, Ho Chi Minh City, 700000, Vietnam] Email: buingoctoan@iuh.edu.vn

(c) Copyright: The Author(s)

This is an Open Access article distributed under the terms of the Creative Commons Attribution Non-Commercial License (https://creativecommons.org/licenses/by-nc/4.0/) which permits unrestricted non-commercial use, distribution, and reproduction in any medium, provided the original work is properly cited.
Ejaz, 2019). Indeed, countries with higher levels of financial development as well as a better-developed banking system and stock market have better financial services than those with a limited financial development (Bencivenga, Smith, \& Starr, 1995; Esso, 2010; King \& Levine, 1993), so the former possess a faster economic growth and poverty reduction than the latter does (King \& Levine, 1993). Admittedly, a majority of earlier studies have examined the impact of financial development on economic growth and poverty reduction. Undeniably, there exists a big gap in the current literature due to a lack of empirical studies considering influential factors of financial development despite their great contribution to a better financial development. On the other hand, there have been contradictory views on the measurement of financial development. Indeed, the International Monetary Fund (IMF) suggests that financial development should be approximated by developments of financial institutions and markets, mainly concentrating on the banking sector and stock market. This is in line with suggestions of Greenwood and Jovanovic (1990), Bencivenga and Smith (1998), Nguyen, Xuan, and Bui (2020). However, most of previous researchers have investigated financial development from the perspective of the banking sector with little investigation from the one of the stock market. An overview of financial 
development, especially identifying its influential factors is thus an interesting topic for more consideration, particularly in emerging economies like Vietnam.

By this study, we provide an overview of financial development in Vietnam, primarily concentrating on answering the question "Which factors affect financial development in Vietnam?". In addition, the data collection is conducted in Vietnam, an emerging country with the absence of financial development's analyses. This study is thus expected to bring an overview of financial development in Vietnam. It is also expected to offer first empirical evidence on specifying determinants of financial development in an emerging economy like Vietnam. Based on its findings, Vietnamese authorities as well as other emerging countries' can adopt appropriate solutions for the sustainable and synchronous financial development.

The remaining part of the paper consists of literature review, research methodology, data analysis and discussion of the findings, and eventually, conclusion.

\section{Literature Review}

Financial development can be defined as improvements in depth, efficiency and access of financial institutions and markets, mainly approximated from the perspective of the banking system and stock market (Bencivenga \& Smith, 1998; Greenwood \& Jovanovic, 1990; Nguyen et al., 2020; Pradhan, Arvin, Hall, \& Bahmani, 2014). In empirical studies, financial development is frequently measured by domestic credit to private sector (Bui, 2019a, 2020; Choi \& Park, 2017; Fisman \& Love, 2003; Lim, 2018; Shen, 2013) and stock market capitalization (Choi \& Park, 2017; Fisman \& Love, 2003; Shen, 2013) which are two indicators of financial depth, an essential element of financial development. Meanwhile, following the financial development index database of the IMF, financial development can be approximated by a combination of depth, efficiency and access of financial institutions and markets. The IMF measure is superior in reflecting multi-dimensional improvements of financial development, overcoming limitations in measures of financial development used in empirical studies. Therefore, we employ the financial development index database of the IMF to provide a comprehensive insight into financial development.

\subsection{Measures of Financial Development}

Following the financial development index database suggested the IMF, financial development can be measured by the depth, efficiency and access of financial institutions and markets. Particularly, financial institutions mainly focus on the banking system while the stock market is the representative of financial markets.
- Financial depth: Financial depth demonstrates the size of financial sector relative to the economy (Bui, 2019a, 2020; Klein \& Olivei, 2008; Zaman, Izhar, Khan, \& Ahmad, 2012). Admittedly, a deeper financial sector captures its stronger capacity in supplying capital to the economy. In developed countries, financial development is frequently approximated by the banking system and stock market relative to the economy while the size of banking system relative to the economy is its main proxy in developing or emerging economies whose stock markets are relatively nascent and small as compared to the economy. Regarding the measures, domestic credit to private sector and stock market capitalization are two indices commonly used as proxies of financial depth (Choi \& Park, 2017; Fisman \& Love, 2003; Shen, 2013).

- Financial efficiency: Financial efficiency refers the improvements in performance from the perspectives of the banking system and stock market. The improved financial efficiency brings households and firms more benefits when using financial services. Financial efficiency is frequently measured by interest rate spread and stock market turnover ratio.

- Financial access: Financial access captures the improvements in the access of the banking system and stock market. In other words, this shows how widely the banking system and stock market spread throughout the population. Financial access from the perspective of the banking system is frequently approximated by bank branches per 100,000 adults and ATMs per 100,000 adults while the ratio of market capitalization outside of the 10 largest companies to total market capitalization is used to measure the access from the perspective of the stock market.

\subsection{Determinants of Financial Development}

In this section, we principally identify factors affecting financial development which have been reported in earlier studies and chosen to be considered in this study, including the real estate market, economic growth, consumer price index, and global financial crisis.

- The real estate market: The real estate market refers where transferring, leasing, consulting and broking are performed (Thu \& Perera, 2011). There have been different views on its measures. However, growth index of business activities in the real estate market is considered as its broadest measure which has been employed by Ni and Liu (2011), Lambertini, Mendicino, and Punzi (2017), Bui (2019a), Nguyen and Bui (2019), Nguyen, Bui, and Nguyen (2019), Nguyen et al. (2020). Particularly, business activities in real estate market mainly focus in the following 
fields including transferring, house or office leasing, consulting and broking. In fact, the real estate market may exert a significant impact on financial development. It is because thanks to its developments, real estate holders can easily access to banking lending through mortgage-backed securities, giving a rise in credits provided by the banking system and then considerably boosting financial development. More than that, it is advantageous for investors to improve their capital access, increase income and expand their investment in the stock market, contributing significantly to financial development from the perspective of the stock market. Alternatively, developments in the real estate market leads to significant improvements of financial development. Nevertheless, crises in the real estate market will considerably influence financial development.

The American financial crisis in the late 2007 is a typical example (Bahmani-Oskooee \& Ghodsi, 2018). The impact of the real estate market on financial development has been reported in many empirical studies. For instance, Gimeno and Martínez-Carrascal (2010), Hott (2011), Igan, Kabundi, Simone, Pinheiro, and Tamirisa (2011), Anundsen and Jansen (2013), Arestis and Gonzalez (2014), Ibrahim and Law (2014), Shen, Lee, Wu, and Guo (2016), Zhao, Zhan, Jiang, and Pan (2017), Nguyen et al. (2020) highlighted the positive effect of the real estate market on financial development from the perspective of banking system.

Other researchers such as Hui, Zuo, and $\mathrm{Hu}$ (2011), Lin and Lin (2011), Su (2011), Su, Chang, and Zhu (2011), Heaney and Sriananthakumar (2012), Hui and Chan (2014), Tsai (2015), Yuksel (2016), Bahmani-Oskooee and Ghodsi (2018) have stated that the real estate market is positively correlated to financial development from the perspective of the stock market. However, with the existence of real estate bubbles, the marker is highly at risk of crisis and dramatic decrease in the future, which is the chief cause of the significant fall in financial development. In other words, the real estate market can negatively affect financial development. Indeed, Liu and $\mathrm{Su}$ (2010), Li, Chang, Miller, Balcilar, and Gupta (2015), Ali and Zaman (2017), Shi, Liu, and Zhang (2017) have revealed the negative of the real estate market on financial development from the perspective of the stock market.

- Economic growth: Economic growth, a vital indicator of the domestic macroeconomy, is significantly related to financial development. Actually, a healthy economic growth enables the banking system and stock market to easily expand their size and improve their performance, which means that financial development is promoted (Guerra, 2017). This effect was first found by Robinson (1952). After that, lots of researchers, namely Goldsmith (1969), Rajan and
Zingales (1998), Khan and Senhadji (2003), Igan et al. (2011), Guerra (2017), Nguyen et al. (2020) have reported similar findings. Nevertheless, an excessive economic growth leads to a potentially risky and unsustainable economy, which may exert a negative influence on financial development (Naceur, Cherif, \& Kandil, 2014; Ram, 1999).

- Consumer price index: Consumer price index which is also an essential indicator of the domestic macroeconomy can considerably affect financial development (Naceur et al., 2014). In fact, a higherlevel index is the root of economic predicaments such as decline in credit demand and solvency, limit in investment, which leads to a fall in financial development (Azariadis \& Smith, 1996; Boyd, Levine, \& Smith, 2001; Moore, 1986). The negative correlation between consumer price index has been found in a big number of empirical studies such as those of Moore (1986), Azariadis and Smith (1996), Boyd et al. (2001), Rousseau and Yilmazkuday (2009), Bittencourt, Gupta, and Stander (2014), Naceur et al. (2014).

- Global financial crisis: Global financial crisis undeniably exerts a considerable influence on financial development of every country (Huang, Leung, \& Qu, 2015) because it can increase risks in the capital market (Golob, Bastic, \& Psunder, 2012) and worries policymakers in developed countries (Zhang, Li, Hui, \& Li, 2016). There however exist few empirical studies revealing the specific impact of global financial crisis on financial development. Of those, Hui and Chan (2014) confirmed that shocks by the American financial crisis was significantly related to the stock markets in Hong Kong and the U.K. In another study, Nguyen et al. (2020) highlighted the positive effect of the global financial crisis on financial development from the perspective of the banking system in Vietnam.

\section{Research Methodology}

By this analysis, we provide an overall of financial development in Vietnam. We also investigate factors affecting the financial development. We employ the Autoregressive Distributed Lag (ARDL) approach suggested by Pesaran, Shin, and Smith (2001) as the primary analysis. This approach is superior by examining the impact among data series in the short run and long run. Furthermore, this is appropriate for models with short (Pahlavani, Wilson, \& Worthington, 2005) and non-stationary time series (Tursoy \& Faisal, 2016), a typical feature of emerging countries' datasets like Vietnam's. This approach has been previously used by Bahmani-Oskooee and Ghodsi (2018), Nguyen et al. (2020). 
Following the mentioned literature review, it can be admitted that financial development (FD) is substantially affected by real estate market (RE), economic growth (EG), consumer price index (CPI), and global financial crisis (GFC). Thus, we suggest the model taking the following equation:

$$
\begin{aligned}
\Delta F D_{t}= & \alpha_{0}+\sum_{j=1}^{k} \lambda_{1} \Delta F D_{t-j}+\sum_{j=0}^{k} \lambda_{2} \Delta R E_{t-j}+\sum_{j=0}^{k} \lambda_{3} \Delta E G_{t-j} \\
& +\sum_{j=0}^{k} \lambda_{4} \Delta C P I_{t-j}+\sum_{j=0}^{k} \lambda_{5} \Delta G F C_{t-j}+\beta_{1} F D_{t-1} \\
& +\beta_{2} R E_{t-1}+\beta_{3} E G_{t-1}+\beta_{4} C P I_{t-1}+\beta_{5} G F C_{t-1}+\varepsilon_{t} \\
\text { Or: } & \\
\Delta F D_{t}= & \alpha_{0}+\sum_{j=1}^{k} \lambda_{1} \Delta F D_{t-j}+\sum_{j=0}^{k} \lambda_{2} \Delta R E_{t-j}+\sum_{j=0}^{k} \lambda_{3} \Delta E G_{t-j} \\
& +\sum_{j=0}^{k} \lambda_{4} \Delta C P I_{t-j}+\sum_{j=0}^{k} \lambda_{5} \Delta G F C_{t-j}+\varphi E C M_{t-1}+\varepsilon_{t}
\end{aligned}
$$

Where $\mathrm{k}$ is the lag length; $\alpha_{0}$ is constant; $\lambda_{1}, \lambda_{2}, \lambda_{3}, \lambda_{4}, \lambda_{5}$ are short term multipliers; $\beta_{1}, \beta_{2}, \beta_{3}, \beta_{4}, \beta_{5}$ are long term multipliers of lagged variables in the model; $\phi$ is the speed of adjustment and ECM is error correction term lagged by one time period.

\subsection{Dependent Variables}

Financial development (FD) is measured from the perspectives of the banking system and stock market with three indices, namely financial depth, financial efficiency, and financial access. Specifically, following the financial development index database of the IMF and some earlier studies, financial depth is approximated by domestic credit to private sector (DC) and stock market capitalization (MC) while financial efficiency is measured by interest rate spread (IR) and stock market turnover ratio (MT). Market access (MA) is chosen as the proxy of financial access.

- Domestic credit to private sector (DC): DC, a proxy of financial depth from the perspective of the banking system, is measured by domestic credit to private sector ( $\%$ of GDP). This is in line with the suggestions of the IMF, Fisman and Love (2003), Shen (2013), Choi and Park (2017), Lim (2018), Bui (2019a, 2020). DC is calculated by growth rate in each quarter (compared to the same period a year earlier).

- Stock market capitalization (MC): As an indicator of financial depth from the perspective of the stock market, $\mathrm{MC}$ is approximated by stock market capitalization ( $\%$ of GDP). This measure follows the financial development index database of the IMF and what some earlier scholars, namely Fisman and Love (2003), Shen (2013), Choi and Park (2017) have performed. MC is also measured by quarterly growth rate (compared to the same period last year).

- Interest rate spread (IR): Following the financial development index database of the IMF, we calculate IR by lending rate minus deposit rate as a proxy of financial efficiency from the perspective of the banking sector.

- Stock market turnover ratio (MT): As a proxy of financial efficiency from the perspective of the stock market, MT is approximated by total value of shares traded during the period divided by the average market capitalization for the period, following the suggestion of the IMF.

- Market access (MA): As an indicator of financial access the perspective of the stock market, MA is calculated by the average market capitalization of the top ten largest companies to the average total market capitalization in each period. Therefore, the increase in MA captures the decline in financial access and vice versa. This measure is based on the financial development index database of the IMF.

The model considering the influential factors of financial development in Vietnam includes five detailed models which are Model 1 (dependent variable: DC), Model 2 (dependent variable: MC), Model 3 (dependent variable: IR), Model 4 (dependent variable: MT), and Model 5 (dependent variable: MA).

\subsection{Independent Variables}

- Real estate market (RE): As a proxy of the real estate market, RE is approximated by quarterly growth rate (compared to the same period last year) of business activities in the real estate market. This measure has been employed by $\mathrm{Ni}$ and Liu (2011), Lambertini et al. (2017), Bui (2019a), Nguyen and Bui (2019), Nguyen et al. (2019), Nguyen et al. (2020).

- Economic growth (EG): EG is calculated by quarterly growth rate (compared to the same period last year) of GDP as an indicator of the domestic macroeconomy.

- Consumer price index (CPI): Also a proxy of the domestic macroeconomy, CPI is measured by quarterly growth rate (compared to the same period last year) of consumer price index.

- Global financial crisis (GFC): We calculate GFC as an indicator of global macroeconomic shocks by using a dummy variable that is equal to 1 during the global financial crisis (from Q3 2007 to Q1 2013) and 0 for the remaining periods. This measure is based on what Cayon, Thorp, and Wu (2018), Kapan and Minoiu (2018) suggested and what Nguyen et al. (2020) have used in their study. 
The data are quarterly collected in Vietnam from Q3 2004 to Q4 2018. This period is chosen in order to assure relatively sufficient observations with the reality of Vietnam's fledgling stock and real estate markets. Particularly, data of DC and IR are obtained from the IMF while data of RE, EG and CPI are collected from the General Statistics Office of Vietnam (GSO). The State Securities Commission of Vietnam (SSC) is the only source for data collection of MC, MT and MA.

\section{Results and Discussion}

The quarterly data of financial development from Q3 2004 to Q4 2018 are shown in Table 1 as follows: Vietnam is known as an emerging country with a limited financial development. In fact, its banking system always plays a major role in supplying credit to the economy. Meanwhile, Vietnam's stock market is also young with many limitations (Bui, 2019b). However, Table 1 shows that MC's mean is much higher than DC's, which means that the stock market possesses a higher growth rate than the banking sector.

In other words, despite being smaller than the banking system (see Figure 1), the stock market has made an impressive increase and been expected to grow considerably in the future. Regarding financial efficiency, IR and MT have remained stable and made some recent improvements. However, credit is still an essential banking service which generates the major income for Vietnam's banks. This is suitable with typical features of emerging economies like Vietnam but also brings many potential risks to banks due to a heavy dependence on profits from lending. Regarding financial access, Table 1 reveals a relatively high MA (the average of $63.1 \%$ ). Big companies in the stock market play a significant role in boosting the market but also put newly established companies in difficulties and have a considerable influence on investors. This is one of the biggest limitations of Vietnam's stock market.
Table 2 shows the result of Dickey-Fuller test suggested Dickey and Fuller (1979). Specifically, IR, MT and EG are stationary at the root time series $\mathrm{I}(0)$ at the $5 \%$ significant level while the other become stationary after taking the first difference I(1) at the $1 \%$ level of significance.

Table 1: Descriptive statistics

\begin{tabular}{|l|c|c|c|c|}
\hline Variable & Mean & Min & Max \\
\hline $\begin{array}{l}\text { Financial } \\
\text { depth }\end{array}$ & DC & 0.246 & 0.080 & 0.632 \\
\cline { 2 - 5 } & MC & 1.316 & -0.530 & 12.503 \\
\hline $\begin{array}{l}\text { Financial } \\
\text { efficiency }\end{array}$ & IR & 0.029 & 0.015 & 0.043 \\
\cline { 2 - 5 } & MT & 0.290 & 0.060 & 1.453 \\
\hline $\begin{array}{l}\text { Financial } \\
\text { access }\end{array}$ & MA & 0.631 & 0.459 & 0.870 \\
\hline
\end{tabular}

Table 2: Dickey-Fuller test result

\begin{tabular}{|l|c|c|}
\hline \multirow{2}{*}{ Variable } & At level & At $\Delta$ \\
\cline { 2 - 3 } & $\mathbf{I}(\mathbf{0})$ & $\mathbf{I}(\mathbf{1})$ \\
\hline DC & 0.471 & $0.002^{* * *}$ \\
\hline MC & 0.364 & $0.000^{* * *}$ \\
\hline IR & $0.035^{* *}$ & $0.000^{* * *}$ \\
\hline MT & $0.043^{* *}$ & $0.000^{* * *}$ \\
\hline MA & 0.251 & $0.000^{* * *}$ \\
\hline RE & 0.117 & $0.000^{* * *}$ \\
\hline EG & $0.045^{* * *}$ & $0.000^{* * *}$ \\
\hline CPI & 0.461 & $0.001^{* * *}$ \\
\hline GFC & 0.562 & $0.000^{* * *}$ \\
\hline
\end{tabular}

Note: ${ }^{* *}$ and ${ }^{* * *}$ indicate significance at the $5 \%$ and the $1 \%$ level, respectively.

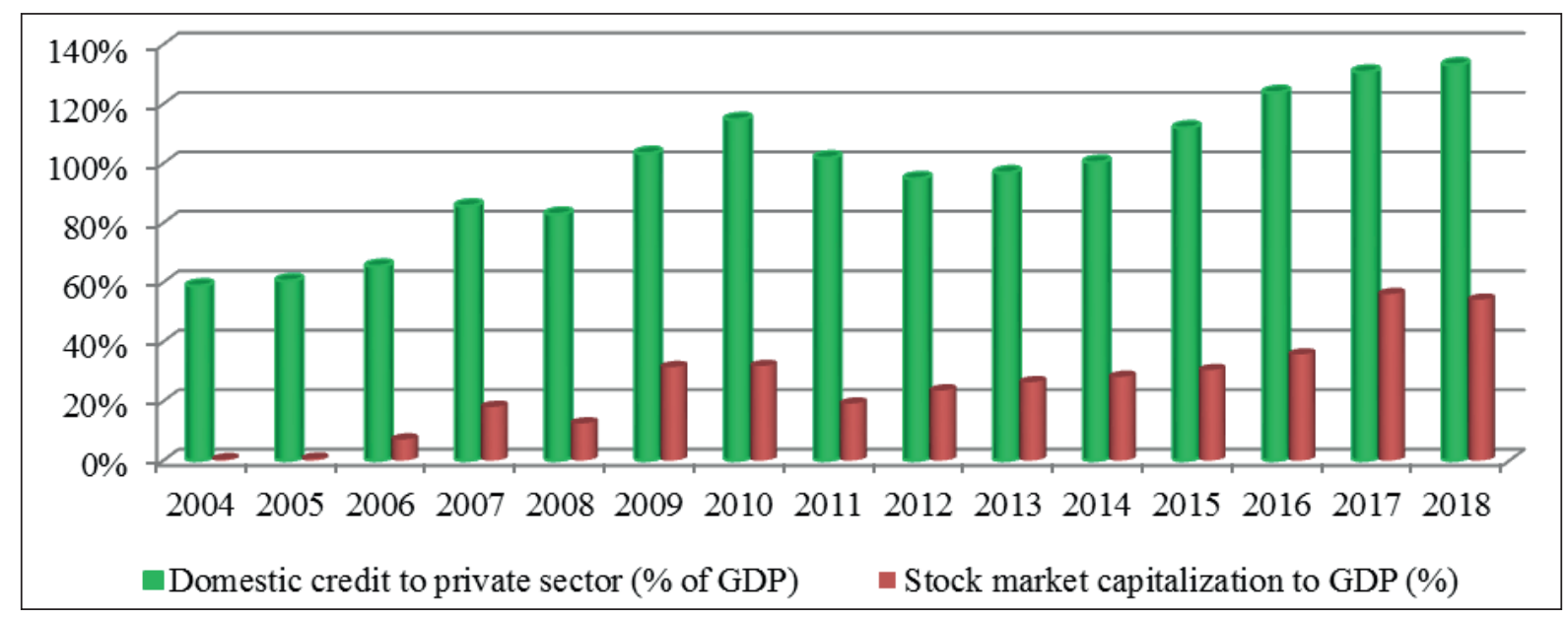

Figure 1: Domestic credit to private sector and stock market capitalization (\% of GDP) in Vietnam 
Table 3: Bound test result

\begin{tabular}{|l|c|c|c|c|c|}
\hline p-value & $\begin{array}{c}\text { Model 1 } \\
\text { (dependent } \\
\text { variable: DC) }\end{array}$ & $\begin{array}{c}\text { Model 2 } \\
\text { (dependent } \\
\text { variable: MC) }\end{array}$ & $\begin{array}{c}\text { Model 3 } \\
\text { (dependent } \\
\text { variable: IR) }\end{array}$ & $\begin{array}{c}\text { Model 4 } \\
\text { (dependent } \\
\text { variable: MT) }\end{array}$ & $\begin{array}{c}\text { Model 5 } \\
\text { (dependent } \\
\text { variable: MA) }\end{array}$ \\
\hline $\mathrm{I}(0)$ & $0.000^{* * *}$ & $0.060^{*}$ & $0.097^{*}$ & $0.078^{*}$ & 0.151 \\
\hline $\mathrm{I}(1)$ & $0.001^{* * *}$ & 0.226 & 0.321 & 0.272 & 0.423 \\
\hline
\end{tabular}

Note: " and ${ }^{* * *}$ indicate significance at the $10 \%$ and the $1 \%$ level, respectively.

Table 4: Model estimation testing results

\begin{tabular}{|c|c|c|}
\hline Variable & Coef. & $P>|z|$ \\
\hline \multicolumn{3}{|l|}{ Long run results } \\
\hline RE & $7.438^{\star * \star}$ & 0.000 \\
\hline$E G$ & $3.962^{* * *}$ & 0.005 \\
\hline $\mathrm{CPI}$ & 0.703 & 0.157 \\
\hline GFC & $0.154^{\star \star \star}$ & 0.009 \\
\hline \multicolumn{3}{|l|}{ Short run results } \\
\hline$\triangle D C(-1)$ & $0.571^{* \star *}$ & 0.000 \\
\hline$\triangle R E$ & $2.001^{* \star *}$ & 0.000 \\
\hline$\triangle E G$ & $1.066^{* * *}$ & 0.006 \\
\hline$\triangle \mathrm{CPI}$ & 0.050 & 0.823 \\
\hline$\triangle \mathrm{CPI}(-1)$ & $-0.408^{*}$ & 0.052 \\
\hline$\triangle \mathrm{CPI}(-2)$ & $-0.655^{\star * *}$ & 0.002 \\
\hline$\triangle G F C$ & $0.041^{* * *}$ & 0.005 \\
\hline $\operatorname{ECM}(-1)$ & $-0.269^{\star \star *}$ & 0.000 \\
\hline Constant & $-0.097^{* * *}$ & 0.000 \\
\hline R-squared & \multicolumn{2}{|c|}{$79.64 \%$} \\
\hline Significance level & \multicolumn{2}{|c|}{ Prob $>F=0.000^{* * *}$} \\
\hline White's test & \multicolumn{2}{|c|}{ Prob $>$ chi2 $=0.436$} \\
\hline Breusch-Godfrey LM test & \multicolumn{2}{|c|}{ Prob $>$ chi2 $=0.147$} \\
\hline Normality test & \multicolumn{2}{|c|}{ Prob $>$ chi2 $=0.315$} \\
\hline Ramsey Reset test & \multicolumn{2}{|c|}{ Prob $>F=0.415$} \\
\hline
\end{tabular}

Note: ${ }^{*}$ and ${ }^{* * *}$ indicate significance at the $10 \%$ and the $1 \%$ level, respectively.

The Bound test result developed by Pesaran et al. (2001) is presented in Table 3. Based on this, we specify the cointegration among the data series in each model. Accordingly, the cointegration really exists in Model 1 (dependent variable: DC) at the 1\% significant level. However, we cannot find the cointegration in the other models. Thus, the ARDL approach will be chosen to consider the short-term and long-term impact among the data series of Model 1.
As can be seen in Table 4, the results testing Model 1 using the ARDL approach valid and significant at the $1 \%$ level. The White's, Breusch-Godfrey LM, Normality and Ramsey Reset tests show valid results, too. Also, both CUSUM and CUSUM squared are within the standard bound at the 5\% significant level (Figure 2). The results thus have stability and can be utilized. On the other hand, its R-squared is $79.64 \%$, which indicates that the independent variables can account for $79.64 \%$ of fluctuations of DC.

It can be concluded that DC is positively affected by RE in the short run $(\lambda=2.001)$ and long run $(\beta=7.438)$ at the $1 \%$ significant level. Meanwhile, EG exerts a positive effect on DC in the short run $(\lambda=1.066)$ and long run $(\beta=3.962)$ at the $1 \%$ significant level. We only find the negative impact of CPI on DC in the short run at the 1-period and 2-period lag at the $1 \%$ and $10 \%$ significant level, respectively. In addition, it can be found that GFC positively affects DC in the short run $(\lambda=0.041)$ and long run $(\beta=0.154)$ at the $1 \%$ level.

The impact of the real estate market on financial development: The results reveal that RE positively affects DC in the short run and long run. This means that growths in the real estate market allows real estate holders to easily access bank loans through mortgage-backed securities, thereby considerably boosting financial development. The positive correlation between RE and DC is in line with what have been reported by Gimeno and Martínez-Carrascal (2010), Hott (2011), Igan et al. (2011), Anundsen and Jansen (2013), Arestis and Gonzalez (2014), Ibrahim and Law (2014), Shen et al. (2016), Zhao et al. (2017), Nguyen et al. (2020). Therefore, it is necessary to aim to a sustainable real estate market and minimize real estate bubbles, the root of crises and sharp decline in the future, which may lead to a significant tumble of financial development (Bahmani-Oskooee \& Ghodsi, 2018).

The impact of economic growth on financial development: By this study, we find the positive effect of EG on DC in the short run and long run. This corroborates the previous findings of Robinson (1952), Goldsmith (1969), Rajan and Zingales (1998), Khan and Senhadji (2003), Igan et al. (2011), Guerra (2017), Nguyen et al. (2020). It can thus be concluded that economic growth plays a vital role in boosting financial development. It should however be developed solidly to assure a sustainable financial development. 


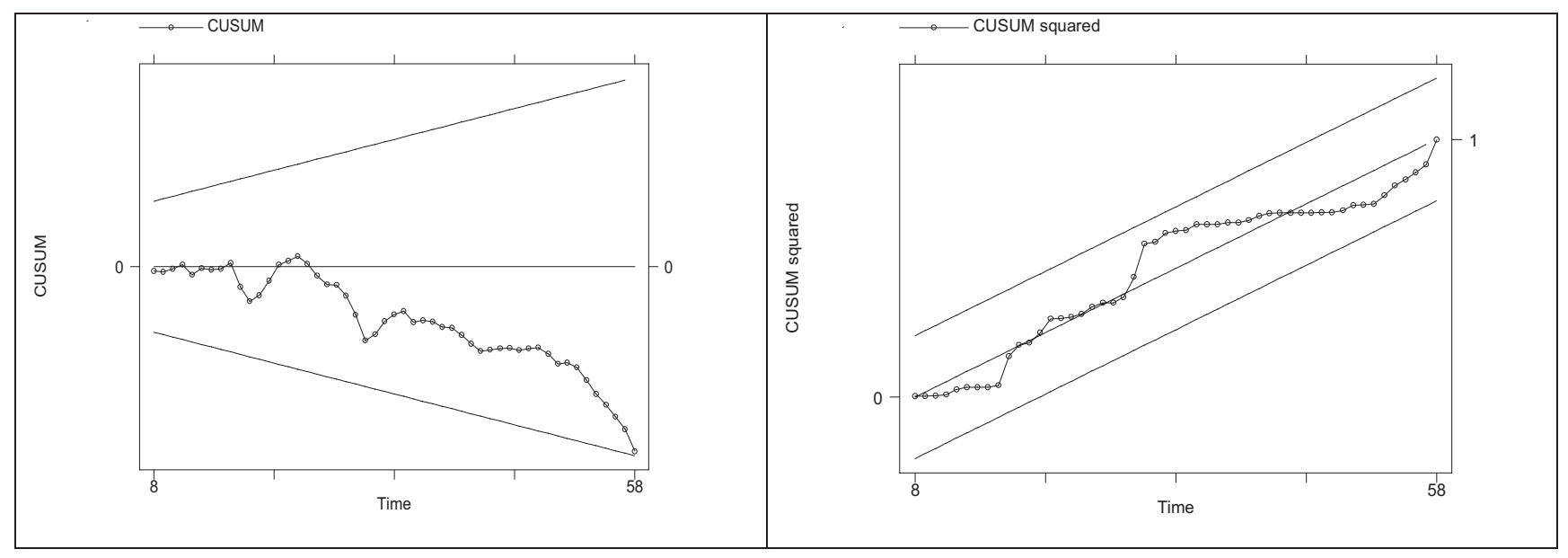

Figure 2: Stability tests

The impact of consumer price index on financial development: In the short run, CPI is correlated to DC at the 1-period and 2-period lag. Accordingly, it is admitted that a highly increased CPI will lead to economic difficulties, decline in credit demand and solvency, and eventually limit in financial development. This is similar to what Moore (1986), Azariadis and Smith (1996), Boyd et al. (2001), Rousseau and Yilmazkuday (2009), Bittencourt et al. (2014), Naceur et al. (2014) have been highlighted. In Vietnam, the authorities have successfully issued flexible macroeconomic policies to stabilize the economy, greatly contributing in fostering financial development, especially lessening the negative long-term impact of CPI on DC.

The impact of global financial crisis on financial development: We find the positive impact of GFC on $\mathrm{DC}$ in the short run and long run which is interestingly in line with the report of Nguyen et al. (2020). The result confirms that shocks by the global financial crisis is significantly related to financial development in Vietnam. This has worried policymakers of Vietnam as well as other countries. Together with the occurrence of the global financial crisis, the domestic economy experienced a big number of predicaments, giving a considerable fall in DC in late 2008. In 2009, however, with the project stimulating the economy at the value of $10 \%$ GDP, the State Bank of Vietnam implemented timely and drastic solutions to credit policy management for the purpose of production encouragement and macroeconomic stability. Therefore, credits supplied by the banking sector started to grow in 2009. Especially, this sector heightens lending manufacturing firms and minimize lending real estaterelated institutions. That is why the credits supplied by the banks still increased and flew in the manufacturing fields during the global financial crisis.

\section{Conclusion}

The study greatly succeeds in giving first empirical evidence on an overview of financial development in Vietnam. The results show that Vietnam is an emerging country with a limited financial development. More specifically, the banking sector is essential in supplying credit to the economy. Meanwhile, despite being nascent and limited, the stock market has an enormous potential. More than that, the study identifies factors considerably affecting financial development in Vietnam, including real estate market (RE), economic growth (EG), consumer price index (CPI), and global financial crisis (GFC). These findings are essential for the authorities in giving practical measures to develop sustainable and synchronous financial development. Following them, we suggest some implications to improve the financial development as follows:

In regards to the real estate market: In fact, a welldeveloped real estate market is a positive signal for the improvements in financial development. It is thus necessary to develop a sustainable real estate market, reducing risks of real estate bubbles. To reach this target, the authorities need to give effective measures in order to: (1) Raise the capital access of the real estate market; (2) Improve the imbalance between demand and supply in the real estate market; (3) Ensure transparency to real estate market-related information.

In regards to the domestic macroeconomic factors: It is important for officials to manage a stable macroeconomic policies and facilitate the improvements of financial development. Particularly, they should be combined with a sustainable development of the banking sector and stock market. Thanks to them, the banking system can successfully uphold a key role in supplying capital to the economy and the stock market can develop and become an effective channel supplying medium- and long-term capital. 
In regards to the global financial crisis: The authorities should carefully keep track and improve the ability of the global economic forecasts. This is fundamental for the application of suitable measures to promote a healthy financial development. More importantly, opportunities brought by the global economic integration should be seized while effective measures should be adopted to alleviate the negative impact caused by unusual fluctuations of the global economy.

Despite achieving its objectives, the study has its own limitations when only considering financial development from the perspectives of banking system and stock market. Due to the limit in data collection, it has not investigated financial development from the perspectives of the insurance market, bond market. In addition, financial stability is included as an index of financial development. These limitations may be interesting proposals for future studies.

\section{References}

Ali, G., \& Zaman, K. (2017). Do house prices influence stock prices? Empirical investigation from the panel of selected European Union countries. Economic Research-Ekonomska Istraživanja, 30(1), 1840-1849. https://doi.org/10.1080/13316 77X.2017.1392882

Anundsen, A. K., \& Jansen, E. S. (2013). Self-reinforcing effects between housing prices and credit. Journal of Housing Economics, 22(3), 192-212. https://doi.org/10.1016/j. jhe.2013.07.001

Arestis, P., \& Gonzalez, A. R. (2014). Bank credit and the housing market in OECD countries. Journal of Post Keynesian Economics, 36(3), 467-489. https://doi.org/10.2753/PKE0160sss3477360304

Azariadis, C., \& Smith, B. D. (1996). Private Information, Money, and Growth: Indeterminacy, Fluctuations, and the MundellTobin Effect. Journal of Economic Growth, 1(3), 309-332. https://doi.org/10.1007/BF00141041

Bahmani-Oskooee, M., \& Ghodsi, S. H. (2018). Asymmetric causality between the U.S. housing market and its stock market: Evidence from state level data. The Journal of Economic Asymmetries, 18, 1-8. https://doi.org/10.1016/j.jeca.2018. e00095

Bencivenga, V. R., \& Smith, B. D. (1998). Economic development and financial depth in a model with costly financial intermediation. Research in Economics, 52(4), 363-386. https:// doi.org/10.1006/reec.1998.0176

Bencivenga, V. R., Smith, B. D., \& Starr, R. M. (1995). Transaction costs, technological choice, endogenous growth. Journal of Economic Theory, 67(1), 53-117. https://doi.org/10.1006/ jeth.1995.1069

Bittencourt, M., Gupta, R., \& Stander, L. (2014). Tax evasion, financial development and inflation: Theory and empirical evidence. Journal of Banking \& Finance, 41, 194-208. https:// doi.org/10.1016/j.jbankfin.2014.01.009

Bong, A., \& Premaratne, G. (2020). The Impact of Financial Integration on Economic Growth in Southeast Asia. Journal of Asian Finance, Economics and Business, 6(1), 107-119. http:// doi.org/10.13106/jafeb.2019.vol6.no1.107

Boyd, J. H., Levine, R., \& Smith, B. D. (2001). The impact of inflation on financial sector performance. Journal of Monetary Economics, 47(2), 221-248. https://doi.org/10.1016/S03043932(01)00049-6

Bui, T. N. (2019a). The Role of Financial Development in the Vietnam Economy. WSEAS Transactions on Business and Economics, 16, 471-476. Retrieved from https://www.wseas. org/multimedia/journals/economics/2019/a985107-854.pdf

Bui, T. N. (2019b). Inflation and stock index: evidence from Vietnam. Journal of Management Information and Decision Sciences, 22(4), 408-414. Retrieved from https://www. abacademies.org/articles/inflation-and-stock-index-evidencefrom-vietnam.pdf

Bui, T. N. (2020). How does financial development affect the employment? Evidence from Asean countries. Journal of Management Information and Decision Sciences, 23(1), 1-6. Retrieved from https://www.abacademies.org/articles/ How-does-financial-development-affect-the-employmentevidence-1532-5806-23-1-174.pdf

Camba, A. C., \& Camba, A. L. (2020). The Dynamic Relationship of Domestic Credit and Stock Market Liquidity on the Economic Growth of the Philippines. Journal of Asian Finance, Economics and Business, 7(1), 37-46. https://doi.org/10.13106/ jafeb.2020.vol7.no1.37

Cayon, E., Thorp, S., \& Wu, E. (2018). Immunity and infection: Emerging and developed market sovereign spreads over the Global Financial Crisis. Emerging Markets Review, 34(C), 162-174. https://doi.org/10.1016/j.ememar.2017.11.006

Cherif, M., \& Dreger, C. (2016). Institutional Determinants of Financial Development in MENA countries. Review of Development Economics, 20(3), 670-680. https://doi. org/10.1111/rode.12192

Choi, C., \& Park, K. (2017). Financial system and housing price. Emerging Markets Finance and Trade, 54(2), 328-335. https:// doi.org/10.1080/1540496X.2017.1344832

Dickey, D. A., \& Fuller, W. A. (1979). Distribution of the Estimators for Autoregressive Time Series with Unit Root. Journal of the American Statistical Association, 74(366), 427-432. https://doi. org/10.2307/2286348

Esso, L. J. (2010). Re-examining the finance-growth nexus: Structural break, threshold cointegration and causality evidence from the ECOWAS. Journal of Economic Development, 35(3), 57-79. Retrieved from http://www.jed.or.kr/full-text/35-3/3.pdf

Fisman, R., \& Love, I. (2003). Trade Credit, Financial Intermediary Development, and Industry Growth. The Journal of Finance, 58(1), 353-374. https://doi.org/10.1111/1540-6261.00527 
Gimeno, R., \& Martínez-Carrascal, C. (2010). The relationship between house prices and house purchase loans: The Spanish case. Journal of Banking \& Finance, 34(8), 1849-1855. https:// doi.org/10.1016/j.jbankfin.2009.12.011

Goldsmith, R. W. (1969). Financial structure and development. New Haven, CT: Yale University Press.

Golob, K., Bastic, M., \& Psunder, I. (2012). Analysis of Impact Factors on the Real Estate Market: Case Slovenia. Inzinerine EkonomikaEngineering Economics, 23(4), 357-367. http:// dx.doi.org/10.5755/j01.ee.23.4.2566

Greenwood, J., \& Jovanovic, B. (1990). Financial development, growth, and the distribution of income. Journal of Political Economy, 98(5), 1076-1107. https://doi.org/10.1086/261720

Guerra, E. A. R. (2017). The economic growth and the banking credit in Mexico: Granger causality and short-term effects, 2001Q1 - 2016Q4. Economía Informa, 406, 46-58. https://doi. org/10.1016/j.ecin.2017.10.004

Heaney, R., \& Sriananthakumar, S. (2012). Time-varying correlation between stock market returns and real estate returns. Journal of Empirical Finance, 19(4), 583-594. https://doi.org/10.1016/j. jempfin.2012.03.006

Hott, C. (2011). Lending behavior and real estate prices. Journal of Banking \& Finance, 35(9), 2429-2442. https://doi. org/10.1016/j.jbankfin.2011.02.001

Huang, D. J., Leung, C. K., \& Qu, B. (2015). Do bank loans and local amenities explain Chinese urban house prices? China Economic Review, 34, 19-38. https://doi.org/10.1016/j. chieco.2015.03.002

Hui, E. C. M., \& Chan, K. K. K. (2014). The global financial crisis: Is there any contagion between real estate and equity markets? Physica A: Statistical Mechanics and its Applications, 405, 216-225. https://doi.org/10.1016/j.physa.2014.03.008

Hui, E. C. M., Zuo, W., \& Hu, L. (2011). Examining the relationship between real estate and stock markets in Hong Kong and the United Kingdom through datamining. International Journal of Strategic Property Management, 15(1), 26-34. https://doi.org/1 0.3846/1648715X.2011.565867

Ibrahim, M. H., \& Law, S. H. (2014). House prices and bank credits in Malaysia: An aggregate and disaggregate analysis. Habitat International, 42, 111-120. https://doi.org/10.1016/j. habitatint.2013.11.006

Igan, D., Kabundi, A., Simone, F. N. D., Pinheiro, M., \& Tamirisa, N. (2011). Housing, credit, and real activity cycles: Characteristics and comovement. Journal of Housing Economics, 20(3), 210231. https://doi.org/10.1016/j.jhe.2011.07.002

Kapan, T., \& Minoiu, C. (2018). Balance Sheet Strength and Bank Lending: Evidence from the Global Financial Crisis. Journal of Banking and Finance, 92(C), 35-50. https://doi.org/10.1016/j. jbankfin.2018.04.011

Khan, M. S., \& Senhadji, A. S. (2003). Financial Development and Economic Growth: A Review and New Evidence. Journal of African Economies, 12(2), 89-110. https://doi.org/10.1093/ jae/12.suppl_2.ii89

King, R. G., \& Levine, R. (1993). Finance and growth: Schumpeter might be right. The Quarterly Journal of Economics, 108(3), 717-737. https://doi.org/10.2307/2118406

Klein, M. W., \& Olivei, G. P. (2008). Capital account liberalization, financial depth, and economic growth. Journal of International Money and Finance, 27(6), 861-875. https://doi.org/10.1016/j. jimonfin.2008.05.002

Kousar, R., Rais, S. I., Mansoor, A., Zaman, K., Shah, S. T. H., \& Ejaz, S. (2019). The Impact of Foreign Remittances and Financial Development on Poverty and Income Inequality in Pakistan: Evidence from ARDL - Bounds Testing Approach. Journal of Asian Finance, Economics and Business, 6(1), 71-81. http://doi.org/10.13106/jafeb.2019.vol6.no1.71

Moore, B. J. (1986). Inflation and financial deepening. Journal of Development Economics, 20(1), 125-133. https://doi. org/10.1016/0304-3878(86)90008-8

Naceur, S. B., Cherif, M., \& Kandil, M. (2014). What drives the development of the MENA financial sector?. Borsa Istanbul Review, 14(4), 212-223. https://doi.org/10.1016/j. bir.2014.09.002

Nguyen, M. L. T., \& Bui, T. N. (2019). Stock market, real estate market, and economic growth: an ARDL approach. Investment Management and Financial Innovations, 16(4), 290-302. https://doi.org/10.21511/imfi.16(4).2019.25

Nguyen, M. L. T., Bui, T. N., \& Nguyen, T. Q. (2019). Relationships between Real Estate Markets and Economic Growth in Vietnam. Journal of Asian Finance, Economics and Business, 6(1), 121128. http://doi.org/10.13106/jafeb.2019.vol6.no1.121

Nguyen, M. L. T., Xuan, P. T. T., \& Bui, T. N. (2020). Causal relationship between banking system development and real estate market. Management Science Letters, 10(1), 41-52. https://doi.org/10.5267/j.msl.2019.8.017

Ni, J., \& Liu, J. (2011). The study in house market and stock market in China-HongKong-US. International Conference on Business and Economics Research, 1, 71-75. Retrieved from http://www.ipedr.com/vol1/16-B00027.pdf

Lambertini, L., Mendicino, C., \& Punzi, M. T. (2017). Expectationsdriven cycles in the housing market. Economic Modelling, $60(\mathrm{C})$, 297-312. https://doi.org/10.1016/j.econmod.2016.10.004

Li, X. L., Chang, T., Miller, S. M., Balcilar, M., \& Gupta, R. (2015). The Co-Movement and Causality between the U.S. Housing and Stock Markets in the Time and Frequency Domains. International Review of Economics \& Finance, 38, 220-233. https://doi.org/10.1016/j.iref.2015.02.028

Lim, T. (2018). Growth, financial development, and housing booms. Economic Modelling, 69, 91-102. https://doi.org/10.1016/j. econmod.2017.09.008

Lin, T. C., \& Lin, Z. H. (2011). Are stock and real estate markets integrated? An empirical study of six Asian economies. 
Pacific-Basin Finance Journal, 19(5), 571-585. https://doi. org/10.1016/j.pacfin.2011.05.001

Liu, Y. S., \& Su, C. W. (2010). The relationship between the real estate and stock markets of China: Evidence from a nonlinear model. Applied Financial Economics, 20(22), 1741-1749. https://doi.org/10.1080/09603107.2010.524616

Pahlavani, M., Wilson, E., \& Worthington, A. C. (2005). Trade-GDP nexus in Iran: An application of the autoregressive distributed lag (ARDL) model. American Journal of Applied Sciences, 2(7), 1158-1165. http://dx.doi.org/10.3844/ ajassp.2005.1158.1165

Pradhan, R. P., Arvin, M. B., Hall, J. H., \& Bahmani, S. (2014). Causal nexus between economic growth, banking sector development, stock market development, and other macroeconomic variables: The case of ASEAN countries. Review of Financial Economics, 23(4), 155-173. https://doi.org/10.1016/j.rfe.2014.07.002

Pesaran, M. H., Shin, Y., \& Smith, R. J. (2001). Bounds testing approaches to the analysis of level relationship. Journal of Applied Econometrics, 16(3), 289-326. https://doi.org/10.1002/ jae. 616

Ram, R. (1999). Financial development and economic growth: additional evidence. The Journal of Development Studies, 35(4), 164-174. https://doi.org/10.1080/00220389908422585

Robinson, J. (1952). The Generalisation of the General Theory in: The Rate of Interest and other Essays. London, UK: Palgrave Macmillan.

Rajan, R. G., \& Zingales, L. (1998). Which capitalism? Lessons from the East Asian crisis. Journal of Applied Corporate Finance, 11(3), 40-48. https://doi.org/10.1111/j.1745-6622.1998. tb00501.x

Rousseau, P. L., \& Yilmazkuday, H. (2009). Inflation, financial development, and growth: A trilateral analysis. Economic Systems, 33(4), 310-324. https://doi.org/10.1016/j. ecosys.2009.06.002

Schumpeter, J. A. (1911). The Theory of Economic Development. Cambridge, MA: Harvard University Press.

Shen, L. (2013). Financial dependence and growth: diminishing returns to improvement in financial development. Economics Letters, $\quad 120(2), \quad 215-219 . \quad \mathrm{https}: / /$ doi.org/10.1016/j. econlet.2013.04.018

Shen, C. H., Lee, Y. H., Wu, M. W., \& Guo, N. (2016). Does housing boom lead to credit boom or is it the other way around? The case of China. International Review of Economics and Finance, 42(C), 349-367. https://doi.org/10.1016/j. iref.2015.10.008
Shi, G., Liu, X., \& Zhang, X. (2017). Time-varying causality between stock and housing markets in China. Finance Research Letters, 22, 227-232. https://doi.org/10.1016/j.frl.2017.06.003

$\mathrm{Su}, \mathrm{C}$. W. (2011). Non-linear causality between the stock and real estate markets of Western European countries: Evidence from rank tests. Economic Modelling, 28(3), 845-851. https://doi. org/10.1016/j.econmod.2010.10.021

Su, C. W., Chang, H. L., \& Zhu, M. N. (2011). A non-linear model of causality between the stock and real estate markets of European countries. Romanian Journal of Economic Forecasting, 1, 41-53. Retrieved from http://www.ipe.ro/rjef/ rjef1_11/rjef1_2011p41-53.pdf

Thu, T. T., \& Perera, R. (2011). Consequences of the two-price system for land in the land and housing market in Ho Chi Minh City, Vietnam. Habitat International, 35(1), 30-39. https://doi. org/10.1016/j.habitatint.2010.03.005

Tran, S. H., \& Nguyen, L. T. (2020). Financial Development, Business Cycle and Bank Risk in Southeast Asian Countries. Journal of Asian Finance, Economics and Business, 7(3), 127135. https://doi.org/10.13106/jafeb.2020.vol7.no3.127

Tsai, I. C. (2015). Dynamic information transfer in the United States housing and stock markets. North American Journal of Economics and Finance, 34, 215-230. https://doi.org/10.1016/j. najef.2015.09.012

Tursoy, T., \& Faisal, F. (2016). Causality between stock price and GDP in Turkey: an ARDL bounds testing approach. Romanian Statistical Review, 64(4), 3-19. Retrieved from http:// www.revistadestatistica.ro/wp-content/uploads/2016/12/ RRS4_2016_A1.pdf

Yuksel, A. (2016). The relationship between stock and real estate prices in Turkey: Evidence around the global financial crisis. Central Bank Review, 16(1), 33-40. https://doi.org/10.1016/j. cbrev.2016.03.006

Zaman, K., Izhar, Z., Khan, M. M., \& Ahmad, M. (2012). The relationship between financial indicators and human development in Pakistan. Economic Modelling, 29(5), 15151523. https://doi.org/10.1016/j.econmod.2012.05.013

Zhang, H., Li, L., Hui, E. C. M., \& Li, V. (2016). Comparisons of the relations between housing prices and the macroeconomy in China's first-, second- and third-tier cities. Habitat International, 57, 24-42. https://doi.org/10.1016/j.habitatint.2016.06.008

Zhao, S. X. B., Zhan, H., Jiang, Y., \& Pan, W. (2017). How big is China's real estate bubble and why hasn't it burst yet? Land Use Policy, 64, 153-162. https://doi.org/10.1016/j. landusepol.2017.02.024 